\title{
Studi Penggunaan Obat Analgesik pada Pasien Pasca Partus Pervaginal dan Sectio Caesarea di RSU Bunda Purwokerto
}

\section{Drug Utilization Studies of Analgesic for Vaginal Delivery and Cesarean Section Patients at RSU Bunda Purwokerto}

\author{
Dina Ratna Juwita*, Nadya Faradani, Much Ilham Novalisa Aji Wibowo \\ Fakultas Farmasi, Universitas Muhammadiyah Purwokerto, Jl. Raya Dukuhwaluh, \\ Dukuhwaluh, Kembaran, Purwokerto 53182, Indonesia \\ *Corresponding author email: dinaratnajuwita@gmail.com
}

Received 1-10-2019 Accepted 11-12-2019 Available online 30-12-2019

\begin{abstract}
ABSTRAK
Persalinan dan pelahiran dapat menimbulkan nyeri. Penanganan nyeri harus dikontrol secara adekuat agar nyeri tersebut tidak berubah menjadi nyeri kronis, sehingga tidak berdampak negatif terhadap morbiditas dan mortalitas ibu hamil. Nyeri tersebut dapat ditangani dengan analgesik. Konsumsi obat tersebut dapat terdistribusi ke ASI yang mengganggu proses menyusui. Oleh karena itu penggunaannya perlu diperhatikan. Tujuan dari penelitian ini adalah untuk mengetahui penggunaan analgesik pada ibu pasca melahirkan yang meliputi penggunaan obat analgesik, intensitas nyeri pada pasien pasca melahirkan, dan efektivitas obat analgesik pada pasien pasca melahirkan di RSU Bunda Purwokerto periode Januari-Maret 2019. Penelitian ini merupakan penelitian noneksperimental dengan desain penelitian deskriptif observasional. Pengambilan data secara prospektif dengan sumber data penelitian yang digunakan yaitu hasil rekam medik dan penilaian nyeri menggunakan Visual Analog Scale. Teknik pengambilan sampel yang digunakan yaitu purposive sampling dengan jumlah sampel yang digunakan yaitu 50. Analisis hasil dalam bentuk persentase yang disajikan dalam bentuk tabel dan gambar. Hasil penelitian menunjukkan bahwa penggunaan obat analgesik yang paling banyak digunakan pada ibu pasca melahirkan normal yaitu asam mefenamat tablet dan pasca sectio caesarea yaitu ketoprofen suppositoria. Intensitas nyeri pada pasien pasca melahirkan berada di kategori nyeri sedang dan obat analgesik yang digunakan efektif untuk mengatasi nyeri pasca melahirkan.
\end{abstract}

Kata kunci: analgesik, melahirkan normal, nyeri, penggunaan obat, sectio caesarea.

\section{ABSTRACT}

Labour and childbirth cause pain that must be treated adequately to prevent the occurrence of chronic pain, which contributes to the negative impact on morbidity and 
mortality of mothers. Pain can be treated with analgesics, but these drugs can be distributed into breast milk, which might disturb the breastfeeding process. Hence, the use of analgesics needs to be considered. The aim of this study is to determine the drug utilization of analgesics, including their use, pain intensity, and their effectiveness, in postpartum patients at RSU Bunda Purwokerto from January to March 2019. This is a non-experimental study with the observational descriptive design. The data of this prospective study involved 50 childbirth women were obtained from their medical records, while the pain was assessed with Visual Analog Scale. Data were analyzed with Microsoft Excel and the conclusion was presented as percentages with tables and images. The results showed that the most used analgesic in vaginal delivery was mefenamic acid, while that in the cesarean section was ketoprofen suppositories. In addition, moderate pain was more often observed in postpartum patients and the use of analgesics was effective for treating pain in postpartum.

Key words: analgesic, drug ultilization, pain, sectio caesarea, vaginal delivery.

\section{Pendahuluan}

Persalinan dan pelahiran menyebabkan kontraksi maupun pembedahan abdomen dan dinding uterus sehingga menimbulkan nyeri (Holmes dan Baker, 2011). Nyeri harus dikontrol secara adekuat agar tidak mempengaruhi sistem di dalam tubuh serta tidak menimbulkan dampak negatif pada morbiditas dan mortalitas ibu melahirkan (Katzung, 2014). Sebanyak 43\% ibu pasca melahirkan mengalami nyeri selama 2 minggu. Nyeri tersebut dapat berubah menjadi nyeri kronik hingga 3 bulan pada 25\% pasien (Munro et al., 2017). Beberapa ibu pasca sectio caesarea mengalami nyeri hingga 1 tahun sebanyak $22 \%$ dan pasca melahirkan secara normal adalah $8 \%$ (Kainu et al., 2016).

Rasa nyeri dapat ditangani dengan obat analgesik yang digolongkan menjadi analgesik opioid dan Nonsteroidal anti-Inflammatory Drugs (NSAID) yang pemilihannya tergantung dari tingkatan nyeri setiap individu (Katzung, 2014). Pemilihan obat untuk ibu pasca melahirkan yang nantinya akan menyusui perlu diperhatikan. Dapat diasumsikan bahwa semua obat yang dikonsumsi tersebut akan terdistribusi ke Air Susu Ibu (ASI) lalu disekresi (Sujata dan Hanjoora, 2014). Ketika seorang ibu menyusui anaknya, maka secara tidak langsung bayi tersebut menerima hasil sekresi obat yang diadministrasikan ke ibu (Katzung, 2014).

Beberapa analgesik kurang aman digunakan pada wanita menyusui ketika nilai Milk/Plasma (M/P) atau Relative Infant Dose (RID) lebih dari 10\% (Depkes RI, 2006). Salah satu yang digunakan pasca melahirkan yaitu morfin, dimana mempunyai nilai RID 5,8-10,7\% (Sutton dan Carvalho, 2017). Sebanyak 41,1\% dokter kandungan di Nigeria meresepkan analgesik opioid, sedangkan parasetamol yang termasuk NSAID diresepkan oleh 4,6\% (Lawani et al., 2014). 
Selama penggunaan opioid, proses menyusui harus dihentikan sementara waktu dan diganti dengan susu formula (Kemenkes, 2013). Namun pemberian ASI pada neonatal sangat penting untuk mencegah resiko Angka Kematian Neonatal (AKN) (Septira dan Anggraini, 2016). AKN di Indonesia tahun 2017 sebanyak 15 per 1.000 kelahiran hidup (Kemenkes RI, 2018). Selain itu, penggunaan NSAID dalam jangka panjang berpotensi menyebabkan resiko pada ibu sendiri. Di antaranya terkait gangguan hati, ginjal, dan kardiovaskuler, serta pendarahan gastrointestinal (Schellack et al., 2015). Berdasarkan uraian di atas, perlu dilakukan penelitian mengenai studi penggunaan obat analgesik pada ibu pasca melahirkan sehingga diketahui penggunaan dengan tepat.

\section{Metode Penelitian}

Jenis penelitian ini merupakan penelitian noneksperimental dengan desain penelitian deskriptif observasional, dengan cara melakukan penelitian pada ibu pasca melahirkan untuk melihat gambaran fenomena yang terjadi pada ibu pasca melahirkan tanpa adanya intervensi. Pengambilan data secara prospektif bertujuan untuk melihat studi penggunan obat analgesik pada ibu pasca melahirkan, baik persalinan secara normal maupun sectio caesarea. Sumber data penelitian yang digunakan yaitu hasil rekam medik dan penilaian nyeri menggunakan Visual Analog Scale pada pasien yang mengalami nyeri pasca melahirkan di RSU Bunda Purwokerto periode JanuariMaret 2019. Sampel penelitian diambil dengan menggunakan teknik purposive sampling berdasarkan kriteri inklusi dan eksklusi.

\section{Hasil dan Pembahasan}

Penelitian ini bertujuan untuk mengetahui penggunaan obat analgesik untuk mengatasi nyeri pada ibu pasca melahirkan di RSU Bunda Purwokerto periode Januari 2019 sampai dengan Maret 2019. Pengambilan sampel pada penelitian ini menggunakan metode purposive sampling yang memenuhi kriteria inklusi dengan rumus estimasi proporsi yang diperoleh sampel sebanyak 50 pasien.

Tabel 1. Karakteristik pasien berdasarkan usia

\begin{tabular}{lc}
\hline Karakteristik Umur & $\mathbf{N}(\%)$ \\
\hline Kelompok usia sectio caesarea & \\
Beresiko (<20 dan $>35$ tahun) & $1(4 \%)$ \\
Tidak beresiko (20-35 tahun) & $24(96 \%)$ \\
Kelompok usia melahirkan normal & \\
Beresiko (<20 dan $>35$ tahun) & $2(8 \%)$ \\
Tidak beresiko (20-35 tahun) & $23(92 \%)$ \\
\hline
\end{tabular}


Karakteristik usia pasien yang paling banyak termasuk ke dalam kategori usia melahirkan tidak beresiko. Usia yang dimaksud adalah lama waktu hidup pasien hingga melahirkan bayi. Sejalan dengan hasil penelitian Afritayeni (2017) bahwa ibu bersalin dengan usia $<20$ tahun dan >35 tahun memiliki peluang yang lebih tinggi untuk mengalami nyeri persalinan berat dibandingkan dengan kelompok usia 2035 tahun. Hal tersebut didukung oleh BKKBN (2016) usia dapat mempengaruhi respon seseorang terhadap nyeri. Usia yang terlalu tua maupun terlalu muda dapat meningkatkan kecemasan pada diri seseorang yang dapat mempengaruhi peningkatan intensitas nyeri. Nyeri persalinan dapat menjadi beresiko karena ibu yang melahirkan pada usia <20 tahun mempunyai kesiapan fisik yang kurang karena kondisi rahim dan panggul yang belum berkembang secara optimal yang dapat meningkatkan resiko kesakitan.

Tabel 2. Karakteristik pasien berdasarkan paritas

\begin{tabular}{lc}
\hline Karakteristik Paritas & $\mathbf{N}(\%)$ \\
\hline Kelompok usia sectio caesarea & \\
Beresiko $(\leq 1$ dan $\geq 4)$ & $22(88 \%)$ \\
Tidak beresiko $(2-3)$ & $3(12 \%)$ \\
Kelompok usia melahirkan normal & \\
Beresiko ( $\leq 1$ dan $\geq 4)$ & $23(92 \%)$ \\
Tidak beresiko $(2-3)$ & $2(8 \%)$ \\
\hline
\end{tabular}

Karakteristik paritas pasien pasca melahirkan normal dan sectio caesarea yang paling banyak pada kelompok paritas beresiko. Hasil penelitian tersebut sejalan dengan Afritayeni (2017) bahwa paritas (banyak kelahiran) pada ibu yang baru pernah melahirkan bayi hidup (primipara) dan yang sudah pernah melahirkan (multipara) mempengaruhi persepsi terhadap nyeri persalinan. Sejalan dengan hal tersebut, menurut Rahmawati et al. (2016), terdapat korelasi antara kecemasan dengan tingkat nyeri persalinan primipara, dimana nyeri yang dirasakan yaitu nyeri sedang. Hal tersebut juga didukung oleh teori Nursalam (2015) bahwa faktor yang menyebabkan nyeri persalinan di antaranya adalah persepsi individu terhadap nyeri, pengalaman lampau, dan stres. Pengalaman persalinan terdahulu membuat ibu merasa lebih siap dan membantu dalam hal pengelolaan manajemen nyeri. Rasa cemas dan takut yang berlebihan akan memperberat persepsi nyeri. Faktor kecemasan yang tinggi pada persalinan primipara akan meningkatkan intensitas nyeri. Hal tersebut dikarenakan rasa cemas dapat memicu stres yang mempengaruhi kemampuan seseorang untuk menahan rasa nyeri. 
Vol.16 No. 02 Desember 2019:265-277

Tabel 3. Penggunaan obat analgesik pasca melahirkan

\begin{tabular}{|c|c|c|c|c|c|c|}
\hline Nama Obat & $\begin{array}{c}\text { Golongan } \\
\text { Obat }\end{array}$ & $\begin{array}{l}\text { Dosis yang } \\
\text { Diberikan } \\
\text { (mg) }\end{array}$ & $\begin{array}{l}\text { Frekuensi } \\
\text { Pemberian }\end{array}$ & $\begin{array}{l}\text { Dosis Lazim } \\
\text { (mg) }\end{array}$ & $\begin{array}{c}\text { Dosis } \\
\text { Maksimal } \\
\text { (mg/ hari) }\end{array}$ & $\begin{array}{c}\text { Kesesuaian } \\
\text { Dosis }\end{array}$ \\
\hline $\begin{array}{l}\text { Kalium } \\
\text { diklofenak }\end{array}$ & NSAID & 50 & $2 x$ & $50-150$ & 150 & Sesuai \\
\hline $\begin{array}{l}\text { Tramadol+ } \\
\text { parasetamol }^{a, b, c}\end{array}$ & $\begin{array}{l}\text { Opioid + } \\
\text { NSAID }\end{array}$ & $\begin{array}{c}\text { Tramadol: } 37,5 \\
\text { PCT: } 325\end{array}$ & $3-4 x$ & $\begin{array}{l}\text { Tramadol: } 50-100 \\
\text { (dimulai } 25 \mathrm{mg} \text { ) } \\
\text { РCT:325-1000 }\end{array}$ & $\begin{array}{c}400 \\
4000\end{array}$ & Sesuai \\
\hline $\begin{array}{l}\text { Asam } \\
\text { mefenamat }^{a, b, c}\end{array}$ & NSAID & 500 & $3 x$ & 500 & 1000 & Sesuai \\
\hline $\begin{array}{l}\text { Dexketoprofen } \\
\text { trometamol }^{\text {a }}\end{array}$ & NSAID & 25 & $3 x$ & 25 & 75 & Sesuai \\
\hline \multirow[t]{2}{*}{ Ketoprofen ${ }^{a, b, c}$} & NSAID & 100 & $2 x$ & 100 & 100 & Sesuai \\
\hline & & 50 & $3 x$ & $25-50$ & 300 & Sesuai \\
\hline
\end{tabular}

Berdasarkan Tabel 3, pemberian obat analgesik pada pasien pasca melahirkan telah sesuai dengan dosis lazim dan tidak melebihi dosis maksimalnya. Hal tersebut didukung oleh Gaskell et al. (2017) bahwa dosis lazim ketoprofen yang efektif untuk mengatasi nyeri yaitu $25-100 \mathrm{mg}$. Nyeri tersebut yaitu kategori nyeri sedang hingga berat, sehingga tepat digunakan untuk pasien pasca bedah. Ketoprofen dipilih karena dapat menurunkan resiko pendarahan serta mual dan muntah.

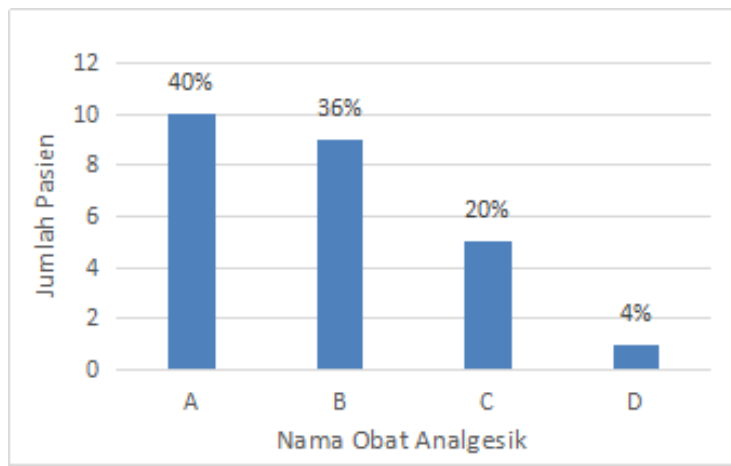

Gambar 1. Distribusi penggunaan obat analgesik pasien sectio caesarea. $A=$ ketoprofen, $B=$ ketoprofen + tramadol + parasetamol, $C=$ ketoprofen + ketoprofen (peroral), $\mathrm{D}=$ ketoprofen + asam mefenamat + dexketoprofen trometamol.

Menurut Pergolizzi et al. (2012) pemberian kombinasi tramadol dan parasetamol dimaksudkan agar memberikan efek obat sinergis. Efektivitas analgesik akan tetap tercapai meskipun dosis obat diturunkan sehingga dapat membatasi efek samping dari tramadol dan parasetamol. Menurut Gaskell et al. (2017) bahwa dosis lazim untuk dexketoprofen trometamol yang efektif untuk mengatasi nyeri yaitu antara 10-25 mg. Menurut Moll et al. 
(2017) dosis asam mefenamat $500 \mathrm{mg}$ efektif untuk pengobatan nyeri sedang hingga berat. Sedangkan menurut Derry et al. (2015), dosis kalium diklofenak yang baik untuk mengatasi nyeri yaitu 50 mg. Berdasarkan Gambar 1. pemberian ketoprofen pasca sectio caesarea merupakan lini pertama. Hal tersebut sesuai dengan Keputusan Menteri Kesehatan Republik Indonesia Nomor 312/ MENKES/ SK/ 2013 tentang Daftar Obat Esensial Nasional 2013 bahwa pemberian ketoprofen suppositoria 100 mg hanya diberikan pada pasien pasca operasi. Selain pemberian ketoprofen secara tunggal, berdasarkan Gambar 1, pasien pasca sectio caesarea diberi obat kombinasi ketoprofen dengan analgesik lainnya. Hal tersebut sejalan dengan Nikles et al. (2005) bahwa kombinasi keduanya digunakan ketika pasien yang diberi analgesik nonnarkotik tidak memberikan respon sehingga diberikan kombinasi keduanya.

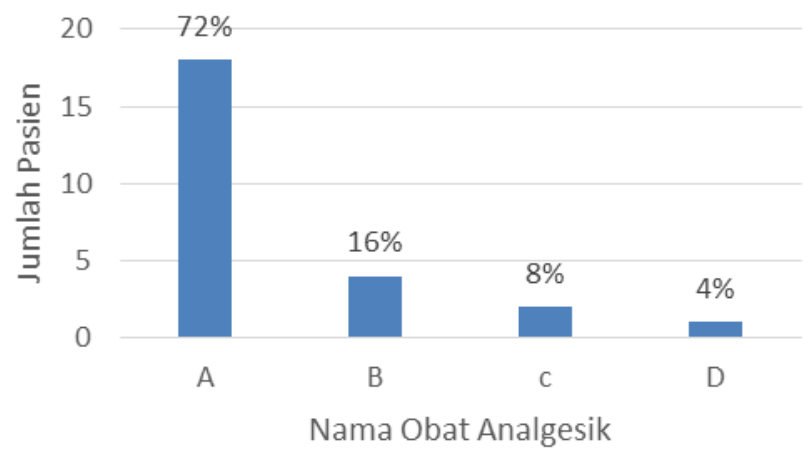

Gambar 2. Distribusi penggunaan obat analgesik pasien melahirkan normal. $A=a s a m$ mefenamat, $B=$ kalium diklofenak, $\mathrm{C}=$ tramadol+parasetamol, $\mathrm{D}=$ dexketoprofen +trometamol.

Berdasarkan Gambar 2, pemberian analgesik yang paling banyak digunakan yaitu asam mefenamat. Asam mefenamat dipilih karena selain sebagai analgesik juga mempunyai kemampuan sebagai antiradang (Katzung, 2014). Respon peradangan digunakan untuk memastikan penyembuhan luka perineum, sehingga mencegah masuknya mikroorganisme penyebab infeksi (Rukiyah et al., 2010).
Pemberian obat secara oral digunakan pada pasien pasca melahirkan normal dan pemberian obat pasca sectio caesarea yang paling banyak digunakan yaitu secara rektal. Menurut teori Anief (2007) rute pemberian mempengaruhi proses absorpsi, distribusi, metabolism, dan ekskresi (ADME). Selain itu, pemilihan bentuk sediaan obat mempengaruhi proses ADME untuk menimbulkan efek terapi. Pemberian 
secara oral umumnya dipilih karena (Matthews, 2017). Anestesi perlu mudah digunakan.

Menurut Baviskar et al. (2013) diberikan kepada pasien prabedah sesuai tata laksananya yang tercantum di dan Derry et al (2012) pemilihan bentuk Keputusan Menteri Kesehatan Republik sediaan suppositoria secara rektal cocok Indonesia Nomor HK. 02. 02/ MENKES/ untuk pasien yang tidak bisa menelan, 251/ 2015 tentang Pedoman Nasional termasuk mual dan muntah. Mual dan muntah tersebut merupakan efek Pelayanan Kedokteran Anestesiologi dan samping dari pemberian anestesi Terapi Intensif.

Tabel 4. Penggunaan obat analgesik berdasarkan rute pemberian dan bentuk sediaan

\begin{tabular}{ll}
\hline Rute Pemberian & N (\%) \\
\hline Pasien sectio caesarea & $11(44 \%)$ \\
$\quad$ Tunggal rektal (suppositoria) & $14(56 \%)$ \\
$\quad$ Kombinasi rektal dan oral (suppositoria dan tablet) & \\
Pasien melahirkan normal & $25(100 \%)$ \\
$\quad$ Oral (tablet) & \\
\hline
\end{tabular}

Tabel 5. Intensitas nyeri pasien pasca melahirkan

\begin{tabular}{lcc}
\hline Jenis Pasien & Rata-Rata Skala Nyeri & Kategori Nyeri \\
\hline Sectio caesarea & 5,4 & Nyeri sedang \\
Melahirkan normal & 5,28 & Nyeri sedang \\
\hline
\end{tabular}

\footnotetext{
Intensitas nyeri yang dialami pada Ibu pasca melahirkan termasuk ketegori nyeri sedang. Kategori tersebut digolongkan sesuai WHO Pain Ladder (2018) dengan skala nyeri 4-6. Hasil tersebut sejalan dengan penelitian Rini dan Susanti (2018) intensitas nyeri pasca sectio caesarea berupa nyeri sedang.

Pemberian obat analgesik disesuaikan dengan derajat nyeri seseorang (Katzung, 2014). Menurut Vijayan et al. (2018) penggunaan tramadol di Asia Tenggara berperan
}

penting dalam pengobatan nyeri sedang hingga berat. Menurut Toms et al. (2008) parasetamol digunakan untuk mengatasi nyeri sedang. Asam mefenamat yang digunakan secara peroral untuk pengobatan nyeri sedang hingga berat (Moll et al., 2017). Menurut Gaskell et al. (2017) ketoprofen dan dexketoprofen efektif untuk mengatasi nyeri sedang hingga berat. 
Tabel 6. Keamanan obat analgesik pada ibu pasca melahirkan

\begin{tabular}{lcc}
\hline \multicolumn{1}{c}{ Nama Obat } & Keamanan & Pedoman \\
\hline Asam Mefenamat & Aman & \\
Tramadol & Aman & \\
Parasetamol & Aman & LactMed \\
Kalium diklofenak & NR & \\
Ketoprofen & NR & \\
Dexketoprofen trometamol & NR & \\
\hline
\end{tabular}

Keterangan; NR=not reported.

Penggunaan analgesik pada Ibu pasca melahirkan yang nantinya menyusui dapat dikatakan aman. Hal tersebut didukung oleh Spigset dan Hagg (2019) asam mefenamat yang tidak mempunyai sifat aditif dirasa cukup aman digunakan. Asam mefenamat memiliki nilai rasio $\mathrm{ASI}$ dan plasma (M/P) yang rendah sehingga transfer obat ke dalam ASI jumlahnya sangatlah kecil. Penggunaan obat tramadol pada ibu pasca melahirkan masih tergolong aman meskipun tramadol merupakan golongan opioid. Efek opioid yang dimiliki tramadol termasuk opioid lemah sehingga tidak terlalu menimbulkan sifat aditif (Katzung, 2014). RID dari metabolit aktif tramadol yang rendah menyebabkan tidak ada efek samping terhadap bayi ketika menerima ASI. Metabolit tersebut akan diekskresikan ke ASI dalam jumlah yang sangat kecil.

Menurut Spigset dan Hagg (2019) penggunaan obat parasetamol untuk wanita menyusui cukup aman karena transfer obat yang tercapai ke ASI jumlahnya sedikit dan meskipun dapat terdeteksi di ASI kadar obatnya rendah. Selain itu WHO (2002) menyebutkan bahwa parasetamol aman untuk ibu menyusui. Kombinasi parasetamol dan tramadol menurut Pergolizzi et al (2012) menunjukkan keamanan untuk menangani nyeri.

Belum ada laporan terkait penggunaan obat diklofenak dan ketoprofen yang terdeteksi jumlahnya pada bayi yang menerima ASI (LactMed, 2018). Tidak ada informasi mengenai jumlah obat dexketoprofen trometamol yang terdeteksi di ASI, namun menurut Matias et al. (2018) penggunaan obat tersebut aman untuk mengatasi nyeri sedang karena efek samping yang ditimbulkan minimal. Menurut ACOG (2018) bahwa secara umum penggunaan NSAID sebagai lini pertama pengobatan nyeri pada ibu pasca melahirkan aman dan efektif.

Keamanan penggunaan obat analgesik pada ibu menyusui berkaitan dengan waktu menyusui, dimana ketika obat yang terdistribusi ke ASI jumlahnya cukup banyak maka perlu dilakukan jeda waktu menyusui (Katzung, 2014). Penggunaan opiod pada ibu menyusui sesuai yang tercantum di Peraturan Menteri Kesehatan Republik Indonesia Nomor 39 Tahun 2013 tentang Susu Formula Bayi dan Produk Bayi Lainnya 
perlu dihentikan sementara waktu dan diganti dengan susu formula. Namun pemberian ASI memiliki lebih banyak keuntungan dibandingkan dengan susu formula, di antaranya yaitu mengurangi pendarahan melahirkan dan sebagai sistem imun bayi. Selain itu, pemberian ASI dapat mengurangi resiko terjadinya Necrotizing Enterocolitis (NEC) atau enterokolitis nekrotikans. Hal tersebut dikarenakan pada masa postnatal, organ pencernaan bayi belum berkembang sempurna sehingga bayi hanya dapat menerima makanan secara oral dalam jumlah yang sedikit (Hermann dan Carol, 2014). Pemberian ASI merupakan salah satu cara untuk mengatasi masalah Berat Bayi Lahir Rendah (BBLR). ASI mengandung kolostrum yang kaya akan protein pada beberapa hari pertama kelahiran sehingga dapat digunakan untuk meningkakan berat badan bayi (Septira dan Anggraini, 2016).

Tabel 7. Intensitas nyeri pasien pasca sectio caesarea berdasarkan waktu

\begin{tabular}{ccccc}
\hline Jam & $\begin{array}{c}\text { Ketoprofen } \\
(\mathbf{n = 9 )}\end{array}$ & $\begin{array}{c}\text { Ketoprofen }+ \\
\text { Tramadol }+ \\
\text { Parasetamol }(\mathbf{n}=\mathbf{9})\end{array}$ & $\begin{array}{c}\text { Rata-Rata Nilai VAS } \\
\text { Ketoprofen }+ \\
\text { Ketoprofen } \\
(\text { Peroral) }(\mathbf{n}=6)\end{array}$ & $\begin{array}{c}\text { Ketoprofen Asam } \\
\text { Mefenamat+Dexketoprofen } \\
\text { Trometamol }(\mathbf{n}=\mathbf{1})\end{array}$ \\
\hline 2 & 4,6 & 5,1 & 5,2 & 6 \\
4 & 4,2 & 4,7 & 4,3 & 6 \\
6 & 3,7 & 4 & 3,8 & 5 \\
8 & 3,1 & 3,6 & 3 & 4 \\
12 & 1,6 & 2 & 1,2 & 2 \\
24 & 0,4 & 1 & 0,5 & 1 \\
\hline
\end{tabular}

Tabel 8. Intensitas pasien pasca melahirkan normal berdasarkan waktu

\begin{tabular}{ccccc}
\hline \multirow{5}{*}{ Jam } & \multicolumn{4}{c}{ Rata-Rata Nilai VAS } \\
\cline { 2 - 5 } & $\begin{array}{c}\text { Asam Mefenamat } \\
(\mathbf{n}=\mathbf{1 8})\end{array}$ & $\begin{array}{c}\text { Kalium Diklofenak } \\
(\mathbf{n}=\mathbf{4})\end{array}$ & $\begin{array}{c}\text { Tramadol + } \\
\text { Parasetamol }(\mathbf{n}=\mathbf{2})\end{array}$ & $\begin{array}{c}\text { Dexketoprofen } \\
\text { Trometamol }(\mathbf{n}=\mathbf{1})\end{array}$ \\
\hline 2 & 4,9 & 4,8 & 5 & 6 \\
4 & 3,3 & 4 & 4 & 5 \\
6 & 2,7 & 2,8 & 2 & 3 \\
8 & 1,7 & 2 & 0 & 1 \\
12 & 0,17 & 0,3 & 0 & 0 \\
24 & 0 & 0 & 0 & 0 \\
\hline
\end{tabular}




\section{Efektivitas Obat Analgesik}

Terdapat penuruan intensitas nyeri berdasarkan nilai VAS pada penggunaan analgesik pasien pasca melahirkan. Hal tersebut sesuai dengan Furdiyanti et al. (2019) bahwa penggunaan ketoprofen pada jam ke-2, 4, 6, 12, dan 24 pada pasien bedah sesar mengalami penurunan derajat nyeri dari sedang menjadi ringan. Menurut Merchante et al. (2013) kombinasi tramadol dan parasetamol efektif untuk beberapa kategori tingkatan nyeri. Husic et al. (2015) menambahkan bahwa kombinasi tramadol dan parasetamol bahkan efektif untuk mengatasi nyeri pada pasien kanker dengan efek samping yang minimal.

Penggunaan dexketoprofen menurut Moore (2008) efektif untuk mengatasi nyeri pasca operasi pada jam ke 4-6 pasca pemberian. Menurut Gazal (2017) parasetamol kurang efektif dibandingkan dengan kalium diklofenak untuk nyeri sedang hingga berat.

Tabel 9. Lama rawat inap

\begin{tabular}{ccc}
\hline Hari & $\begin{array}{c}\text { Sectio Caesarea } \\
\mathbf{N}(\%)\end{array}$ & $\begin{array}{c}\text { Melahirkan Normal } \\
\mathbf{N}(\%)\end{array}$ \\
\hline 2 & - & $22(88 \%)$ \\
3 & $18(72 \%)$ & $3(12 \%)$ \\
4 & $5(20 \%)$ & - \\
5 & $2(8 \%)$ & - \\
\hline
\end{tabular}

Lama rawat inap pasien sectio caesarea paling banyak 3 hari dan melahirkan normal 2 hari. Menurut Bowers dan Chryne (2016) lama rawat inap berhubungan dengan perawatan yang diterima pasca melahirkan, yaitu terkait dengan pemberian obat dan biaya yang dikeluarkan. Khususnya pemberian NSAID dalam jangka panjang berpotensi menyebabkan gangguan fungsi hati, ginjal dan kardiovaskuler, serta pendarahan gastrointestinal (Schellack et al., 2015).

\section{Simpulan}

Penggunaan obat analgesik di RSU Bunda Purwokerto periode Januari-
Maret 2019 pada pasien pasca sectio caesarea yang paling banyak digunakan yaitu ketoprofen suppositoria serta pada pasien pasca melahirkan normal yang paling banyak digunakan yaitu asam mefenamat tablet. Intensitas nyeri pada pasien pasca melahirkan di RSU Bunda Purwokerto periode Januari-Maret 2019 termasuk kategori nyeri sedang dan penggunaan obat analgesik pada pasien pasca melahirkan dapat dikatakan efektif untuk menurunkan nyeri.

\section{Daftar Pustaka}

[ACOG] The American College of Obstetricians and Gynecologist. 2018. Postpartum pain 
management. Obstetricians and Gynecologist, 132:35-43.

Afritayeni. 2017. Hubungan umur, paritas dan pendamping persalinan dengan intensitas nyeri persalinan kala I. Journal Endurance, 2(2):178-185.

Baviskar, P., Bedse, A., Sadique, S., Kunde, V., Jaiswal, S. 2013. Drug delivery on rectal absorption: suppositories. International Journal of Pharmaceutical Sciences Review and Research, 21(1):70-76.

[BKKBN] Badan Kependudukan dan Keluarga Berencana Nasional. 2016. Laporan Kinerja Intansi Pemerintah 2016. Jakarta: Badan Kependudukan dan Keluarga Berencana Nasional.

Bowers, J. dan Chryne, H. 2016. Reducing the length of postnatal hospital stay: implication for cost and quality of care. BMC Health Services Research, 16:1-12.

[Depkes RI] Departemen Kesehatan RI. 2006. Pedoman Pelayanan Farmasi untuk Ibu Hamil dan Menyusui. Jakarta: Departemen Kesehatan RI.

Derry, C.J., Derry, S., Moore, R.A. 2012. Sumatriptan (rectal route o administration) for acute migrain attacks in adults (review). The Cochrane Database of Systematic Reviews, 2:1-34.

Derry, S., Wiffen, P.J., Moore, R.A. 2015. Single dose oral diclofenac for acute postoperative pain in adults. Cochrane Database of
Systematic Reviews, 2015(7): CD004768.

Gazal, G. dan Al-Samandani, K.H. 2017. Comparison of paracetamol, ibuprofen, and diclofenac potassium for pain relief following dental extractions and deep cavity preparations. Saudi Medical Journal, 38(3):285-291.

Furdiyanti, N.H., Oktianti, D., Rahmadi, R., Coreira, L. 2019. Keefektifan ketoprofen dan ketorolak sebagai analgesik pada pasien pasca bedah cesar. Indonesian Journal of Pharmacy and Natural Product, 2:32-47.

Gaskell, H., Derry, S., Wiffen, P.J., Moore, R.A. 2017. Single dose oral ketoporfen or dexketoprofen for acute postoperative pain in adults. The Cochrane Database of Systematic Reviews, 5(5):CD007355.

Hermann, K. dan Caroll, K. 2014. An exclusively human milk diet reduces necrotizing enterocolitis. Breastfeeding Medicine, 9:184-190.

Holmes, D. dan Baker, P.N. 2011. Buku Ajar Ilmu Kebidanan. Penerjemah Mardella, E.A. Jakarta: Penerbit Buku Kedokteran EGC.

Husic, S., Izic, S., Matic, S., Sukalo, A. 2015. Efficacy and safety of a fixed combination of tramadol and paracetamol (acetaminophen) as pain therapy within palliative medicine. Materia Socio-Medica, 27(1):4247. 
Kainu, J.P., Halmesmaki, E., Korttila, K.T., Sarvela, P.J. 2016. Persistent pain after cesarean delivery and vaginal delivery: a prospective cohort study. Anesthesia \& Analgesia, 123(6):1535-1545.

Katzung, B.G. 2014. Farmakologi: Dasar dan Klinik. Edisi 12 Volume 1. Penerjemah Pendit, B.U. Jakarta: Penerbit Buku Kedokteran EGC.

[Kemenkes RI] Kementerian Kesehatan RI. 2013. Keputusan Menteri Kesehatan Republik Indonesia Nomor 312/ MENKES/ SK/ 2013 tentang Daftar Obat Esensial Nasional 2013. Jakarta: Kementerian Kesehatan RI.

[Kemenkes RI] Kementerian Kesehatan RI. 2018. Data dan Informasi: Profil Kesehatan Indonesia 2017. Jakarta: Kementerian Kesehatan RI.

[LactMed] National Library of Medicine. 2018. Drugs and Lactation Database. Seatle: National Library of Medicine.

Lawani, L.O., Eze, J.N., Anozie, O.B., lyoke, C.A., Ekem, N.N. 2014. Obstetric analgesia for vaginal birth in contemporary obstetrics: a survey of the practice of obstetricians in Nigeria. BMC Pregnancy and Childbirth, 14(140):1-6.

Merchante, I.M., Pergolizzi, J.V., van de Laar, M., Mellinghoff, H.U., Nalamachu, S., O'Brien, J., Perrot, S., Raffa, R.B. 2013. Tramadol/paracetamol fixeddose combination for chronic pain management in family practice: a clinical review. ISRN Family Medicine, 2013:1-15.

Matias, R.R.R., Leochico, C.F.D., Nilo, G.S. 2018. Effectiveness and safety of oral dexketoprofen for mild to moderate pain among filipino adults: a post-marketing surveillance study. Journal of Pain and Relief, 7: 1-7.

Matthews, C. 2017. A review of nausea and vomitting in the anaesthetic and post anaesthetic environment. Clinical Feature, 27:224-227.

Moll, R., Derry, S., Moore, R.A., McQuay, H.J. 2017. Single dose oral mefenamic acid for acute postoperative pain in adults. The Cochrane Database of Systematic Reviews, 2011(3): CD007553.

Moore, R.A. dan Barden, J. 2008. Systematic review of dexketoprofen in acute and chronic pain. BMC Clinical Pharmacology, 8:1-11.

Munro, A., George, R.B., Chorney, J., Snelgrove-Clarke, E., Rosen, N.O. 2017. Prevalence and predictors of chronic pain in pregnancy and postpartum. Journal of obstetrics and gynaecology Canada, 39(9):734-741.

Nikles, C.J., Yelland, M., Del Mar, C., Wilkinson, D. 2005. The role of paracetamol in chronic pain: an evidence-based approach. American Journals of Therapeutics, 12:80-91. 
Nursalam. 2015. Manajeman Keperawatan. Jakarta: Salemba Medika.

Pergolizzi, J.V., van de Laar, M., Langford, R., Mellinghoff, H.U., Merchante, I.M., Nalamachu, S., O'Brien, J., Perrot, S., Raffa, R.B. 2012. Tramadol/paracetamol fixeddose combination in the treatment of moderate to severe pain. Journal of Pain Research, 5: 327-346.

Rahmawati, A., Hartati, Sumarni. 2016. Analisis hubungan tingkat kecemasan dan nyeri persalinan kala I primipara. Jurnal Litbang Kota Pekalongan, 10:42-49.

Septira, S. dan Anggraini, D.I. 2016. Nutrisi bagi bayi berat lahir rendah (BBLR) untuk mengoptimalkan tumbuh kembang. Majority, 5:151-155.

Rini, S. dan Susanti, H. 2018. Penurunan nyeri pada ibu post sectio caesaria pasca intervensi biologic nurturing baby led feeding. Medisains: Jurnal Ilmiah IImu-IImu Kesehatan, 16:83-88.

Rukiyah, A.Y., Yulianti, L., Liana, M. 2010. Asuhan Kebidanan I. Jakarta: CV. Tunas Info Media.

Schellack, N., Schellack, G., Fourie, J. 2015. A review of nonsteroidal anti-inflammatory drugs. South African Pharmaceutical Journal, 82:8-18.
Spigset, O. dan Hagg, S. 2000. Analgesic and breastfeeding: safety considerations. Peadiatric Drugs, 2(3):223-238.

Sujata, N. dan Hanjoora, V.M. 2014. Pain control after cesarean birthwhat are the options? Journal of General Practice, 02(4):1-4.

Sutton, C.D. dan Carvalho, B. 2017. Optimal pain management after cesarean delivery. Anesthesiology Clinics, 35:107124.

Toms, L., McQuay, H.J., Derry, S., Moore, R.A. 2008. Single dose oral paracetamol (acetaminophen) for acute postoperative pain in adults. The Cochrane database of systematic reviews, 4:1-3.

Vijayan, R., Afshan, G., Bashir, K., Cardosa, M., Chadha, M., Chaudakshetrin, P. 2018. Tramadol: a valuable treatment for pain in southeast asia countries. Journal of Pain Research, 11: 2567-2575.

[WHO] World Health Organization. 2002. Breastfeeding and Maternal Medication. Switzerland: World Health Organization.

[WHO] World Health Organization. 2019. WHO's Cancer Pain Ladder for Adults. Seattle: World Health Organization. 